\title{
Stem cell factor and IgE-stimulated murine mast cells produce chemokines (CCL2, CCL17, CCL22) and express chemokine receptors
}

\author{
S. H. P. Oliveira and N. W. Lukacs \\ University of Michigan Medical School - Department of Pathology, 1301 Catherine ${ }^{\text {st }}$, Ann Arbor, MI 48109-0602, Fax: 734-764-2397, \\ e-mail: nlukacs@umich.edu
}

Received 31 August 2000; returned for revision 10 November 2000; accepted by L. G. Letts 17 November 2000

\begin{abstract}
Objective and design: In the present study we investigated the effect of SCF and/or IgE on histamine, TNF$\alpha$ and chemokines released from bone marrow-derived mast cells (BMMC) as well as chemokine receptor expression. Material and methods: BMMC were derived from femoral bone marrow of $\mathrm{CBA} / \mathrm{J}$ mice. The purity of BMMC was $>98 \%$ after 3 weeks. BMMC $\left(2.5 \times 10^{6}\right.$ cells/well $)$ were incubated in the presence or absence of either SCF, IgE plus DNP or a combination of SCF and IgE for 6 and $18 \mathrm{~h}$. Cellfree supernatants were recovered to measure CC chemokines, TNF- $\alpha$ and histamine release utilizing ELISA assays. CC chemokine family receptors were detected by RT-PCR analysis, and confirmed using functional chemotactic assays. Results: Histamine levels were comparable between SCF and IgE stimulated cells, whereas TNF- $\alpha$ production was significantly greater after IgE compared to SCF stimulation. SCF and/or IgE-stimulated BMMC released CC chemokines, CCL22 (MDC), CCL17 (TARC) and CCL2 (MCP-1). Increased mRNA expression of CCR1, CCR2, CCR3, and CCR5 was detected in SCF and IgE-stimulated BMMCs. Functional chemotactic assays confirmed the expression data. Conclusion: SCF and IgE can up-regulate the expression of chemokines and chemokine receptors on mast cells. Thus, SCF may play a significant role in their activation and inflammation during allergic responses.
\end{abstract}

Key words: $\mathrm{SCF}-$ Mast cells $-\mathrm{CC}$ chemokine $-\mathrm{CC}$ chemokine receptor - Histamine - TNF- $\alpha$

\section{Introduction}

Mast cells are multifunctional cells that can initiate or modulate various inflammatory processes. These cells contain many preformed mediators that, when released, may induce initial and necessary interactions between circulating leukocytes and the endothelium of postcapillary venules [1]. The

Correspondence to: N. W. Lukacs activation and degranulation of mast cell populations are responses that can be mediated by either antigen-specific, surface bound IgE or by stem cell factor (SCF) [2]. IgEmediated mast cell activation induces immediate mast cell degranulation that constitutes the primary mechanism that drives the allergic responses in terms of type I hypersensitivity response. During this activation, mast cells release preformed and newly synthesized pro-inflammatory mediators including histamine, heparin, proteases, prostaglandin $\mathrm{D}_{2}$, leukotriene $\mathrm{C}_{4}$, and cytokines. In addition, murine mast cells challenged in an IgE-dependent manner or with other stimuli can produce multiple chemokines, including CCL3 (MIP$1 \alpha$ ), CCL4 (MIP-1 $\beta$ ) and CCL2 (MCP-1) that can initiate and perpetuate an inflammatory cascade [3].

CC chemokines are chemotactic cytokines that can induce mediator secretion and chemotaxis of leukocytes [4]. The secretion of chemokines has been detected in a wide variety of cells, including macrophages, endothelial cells, epithelial cells, smooth muscle cells, fibroblasts, lymphocytes, neutrophils, eosinophils and mast cells $[5,6]$. High levels of chemokines have been detected during in vivo inflammatory reactions, such as bacterial sepsis [7], autoimmune reaction [8], and bronchial asthma allergic disorders [9-11]. However, the specific mast cell-derived chemokines that function in these different inflammatory processes have not been completely elucidated.

Stem Cell Factor (SCF) or c-kit receptor ligand has been identified as a primary cytokine involved in mast cell differentiation and activation [12-15]. SCF binds to its surface receptor, c-kit, which is a member of the receptor tyrosine kinase family and SCF has a role in mast cell survival, as mast cells cultured without SCF undergo apoptosis [16]. Furthermore, SCF enhances IgE-dependent human mast cell mediator release, including the generation and release of cytokines [17-19]. Thus, the prolonged activation of mast cell populations by SCF, after initial IgE-mediated events or by itself, may play a significant role in late phase asthma responses.

In the present study we investigated the role of both SCF and IgE-dependent mechanisms for histamine release and 
chemokine and TNF- $\alpha$ production by bone marrow-derived murine mast cells. In addition, we evaluated the ability of SCF and/or IgE-mediated mast cell activities to increase the expression of specific chemokine receptors. Our data demonstrated that SCF is a potent mast cell activator, which can stimulate the expression of both CC chemokine and chemokine receptors, TNF- $\alpha$ and induce the release a mast cell mediator histamine.

\section{Materials and methods}

\section{Isolation and expansion of bone marrow-derived mast cells}

Primary mast cell lines were derived from femoral bone marrow of pathogen-free CBA/J mice (Jackson Laboratory, Bar Harbor, ME) [20]. The cells were incubated with Dulbecco's modified Eagle's medium (DMEM - Bio Whittaker, Walkersville, MA) supplemented with $1 \mathrm{mM}$ L-glutamine, $10 \mathrm{mM} \mathrm{N}$-2-hydroxiethylpiperazine-NI-2-ethanesulfonic acid (HEPES), antibiotics, and $15 \%$ fetal calf serum (FCS) combine with $10 \%$ T-stimulated rat splenocyte culture supplement medium with IL-3 $(15 \mathrm{ng} / \mathrm{ml})$ and SCF $(15 \mathrm{ng} / \mathrm{ml})$. Without addition of exogenous SCF there was poor mast cells growth. The media was changed every three days. By the end of 2-3 weeks, a nonadherent population of large granular cells was observed. These isolated cells appeared homogeneous in cytospin preparations stained by Diff Quik (Baxter, MacGraw Park, IL) with typical mast cell granular appearance. The homogeneity of these cell lines was determined by flow cytometric analysis of surface markers, by histamine release assays, and by electron microscopy. In particular, these cells were $c$-kit positive (SCF receptor) but were negative for $\mathrm{CD} 3, \mathrm{CD} 4, \mathrm{CD} 8, \mathrm{CD} 23, \mathrm{~B} 220$, and $\mathrm{F} 480$ by flow cytometric. The purity of BMMC was $>98 \%$. These cell lines were routinely expanded, as described above, for 3 to 6 weeks. Before each experiment, BMMC were washed and new medium was added without SCF.

\section{Stimulation of BMMC with murine recombinant SCF and/or IgE plus dinitrophenyl (DNP)}

Bone marrow-derived mast cells $\left(2.5 \times 10^{6}\right.$ cells/well $)$, were incubated in complete DMEM with $15 \%$ FCS in the presence or absence of either SCF in different concentrations $(0.1,1,10,100$ and $200 \mathrm{ng} / \mathrm{ml}), \mathrm{IgE}$ $(2 \mathrm{~g} / \mathrm{ml})$ plus DNP $(100 \mathrm{ng} / \mathrm{ml})$ or a combination of SCF $(100 \mathrm{ng} / \mathrm{ml})$ and IgE plus DNP at $37^{\circ} \mathrm{C}$ in $5 \% \mathrm{CO}_{2}$ for 6 and $18 \mathrm{~h}$. After stimulation, cells were centrifuged and the cell-free supernatant recovered to measure CC chemokines, TNF- $\alpha$ and histamine release.

\section{Quantification of CC chemokines and TNF- $\alpha$}

Extracellular immunoreactive murine CC chemokines (MCP-1, MDC, TARC) and TNF- $\alpha$ were quantified using a modified double ligand procedure of enzyme-linked immunosorbent assay (ELISA) [21]. This ELISA method consistently detected CC chemokine or TNF- $\alpha$ levels over $20 \mathrm{pg}$ and did not cross-react with other cytokines. 96-well-flatbottomed microtiter plates were coated with $50 \mu \mathrm{l} /$ well of either rabbit anti-CC chemokine antibodies or anti-TNF- $\alpha(1 \mathrm{~g} / \mathrm{ml}$ in $0.6 \mathrm{M} \mathrm{NaCl}$, $0.26 \mathrm{M} \mathrm{H}_{3} \mathrm{BO}_{4}$, and $0.08 \mathrm{~N} \mathrm{NaOH}, \mathrm{pH} 9.6$ ) for $16 \mathrm{~h}$ at $4{ }^{\circ} \mathrm{C}$, and the washed (PBS, pH 7.5, $0.05 \%$ Tween 20). Blocking of nonspecific binding sites was accomplished by incubating plates with PBS containing $2 \% \mathrm{BSA}$ for $90 \mathrm{~min}$ at $37^{\circ} \mathrm{C}$. Plates were rinsed thoroughly with wash buffer and aqueous samples were added. Following a 1-hours incubation at $37^{\circ} \mathrm{C}$, plates were washed and biotinylated rabbit either anti-CC chemokine or anti-TNF- $\alpha$ Ab was added and incubated for $30 \mathrm{~min}$ at $37^{\circ} \mathrm{C}$. Plates were then washed and chromogen substrate added, and they were subsequently read at $490 \mathrm{~nm}$.

\section{Histamine release assays.}

Histamine ELISA kits (Immunotech, Westbrook, ME) were used to determined histamine levels in supernatants from stimulated mast cells. As positive controls, mast cells were exposed to compound $48 / 80$ (Sigma), a mast cell degranulator, and cells were sonicated to determine total intracellular histamine levels.

\section{Reverse transcription (RT)-PCR analysis}

Total cellular RNA was extracted from 2,5 × $10^{6}$ BMMC using TRIzol reagent (Life Techonologies). Synthesis of first-strand cDNA was performed in $20 \mu \mathrm{l}$ of reaction mixture containing $2 \mu \mathrm{g}$ RNA, $1 \mu \mathrm{dNTP}$ $100 \mathrm{mM}, 5 \mu \mathrm{l}$ oligo $(\mathrm{dT})_{12-18}$ primer $0.5 \mathrm{mg} / \mathrm{ml}, 5 \mu \mathrm{l}$ Rnase inhibitor $40 \mathrm{U} / \mathrm{ml}, 5 \mu \mathrm{l}$ reverse transcriptase $25 \mathrm{U} / 1$ (Boehringer Mannheim, Mannheim, Germany) incubated at $650 \mathrm{C}$ for $7 \mathrm{~min}$, and then incubated at $37^{\circ} \mathrm{C}$ for $1 \mathrm{~h}$. The AMV reverse transcriptase was denatured by $90^{\circ} \mathrm{C}$ for $5 \mathrm{~min}$ and then placed on ice. Sequences of the primers for the amplification were CCR1 (sense 5'-gaccagcatctacctgttca-3'; and antisense, 5"'-gcagaaacaaatacactcag- $3^{\prime}$ ), CCR2 (sense 5'-cacgaagtatccaagagc- $3^{\prime}$; and antisense $5^{\prime}$-catgctcttcagcttttac-3'), CCR3 (sense $5^{\prime}$-tgggcaacatgatggttgtg- $3^{\prime}$; and antisense $5^{\prime}$-gctgtcttgagactcatgga-3'), CCR4 (sense $5^{\prime}$-cctgcctcctctctactcct- $3^{\prime}$; and antisense $5^{\prime}$ - acgtgtggttgtgctctgtg$3^{\prime}$ ), CCR5 (sense 5'-gctgaagagcgtgactgata-3'; and antisense 5'-gaggactgcatgtataatga- $\left.3^{\prime}\right)$. Reverse transcriptase reaction mixture was used in the polymerase chain reaction (PCR) in $20 \mu \mathrm{l}$ final volume, $0.5 \mu \mathrm{l}$ of each dNTP $100 \mathrm{mM}, 2 \mu \mathrm{l}$ of each primer $300 \mathrm{ng} / \mathrm{l}$ and $1.5 \mu \mathrm{l}$ of Taq DNA polymerase $5 \mathrm{U} / \mathrm{ml}$ (Boehringer Mannheim). The mixture was incubated in a thermocycler using the following temperature profile: denaturation step at $94{ }^{\circ} \mathrm{C}$ for 4 minutes, followed by 35 cycles (CCR1, CCR 4 and CCR5) and 30 cycles (CCR2 and CCR3) of denaturation at $94^{\circ} \mathrm{C}$ for 45 seconds, annealing at $55^{\circ} \mathrm{C}$ for 45 seconds, and extension at $72{ }^{\circ} \mathrm{C}$ for 45 seconds. The final extension step was $72^{\circ} \mathrm{C}$ for $10 \mathrm{~min}$. PCR samples were run on a $2 \%$ agarose gel stained with $10-\mathrm{mg} / \mathrm{ml}$ ethidium bromide, and the PCR products were visualized with UV light and photographed.

\section{Mast cell chemotaxis}

Mast cell migration was quantitated by a modification of a Boyden chamber technique described previously [29]. Mast cells were suspended at $3 \times 10^{6}$ cells $/ \mathrm{ml}$ in DPBS plus $0.5 \%$ BSA and were placed in the top wells of the microchemotaxis chamber. Bottom wells were filled with CC chemokines in the final concentration of $50 \mathrm{ng} / \mathrm{ml}$ or assay medium as negative control. An 8-m-pore-size polycarbonate filter separated the upper wells containing the cells from the control and chemokines samples in the bottom wells. The polycarbonate filters used in these experiments were coated with fibronectin $(10 \mathrm{~g} / \mathrm{ml})$ at room temperature overnight and were then air-dried. The chambers were incubated for $2 \mathrm{~h}$ at $37^{\circ} \mathrm{C}$ in a $5 \% \mathrm{CO}_{2}$ moist atmosphere, and the filters were then carefully scraped of nonmigrating cells, fixed with methanol and stained with Diff-Quik. Mast cell migration was quantitated by counting the number of mast cells migrating completely through the matrix-coated filter in 10 high-powered fields (hpf) in triplicate samples. The data are expressed as the average number of countable adherent cells per hpf $( \pm$ SEM).

\section{Statistical analysis.}

Statistical significance was determined by ANOVA, and significance was determined with $\mathrm{p}$ values $<0.05$. 
Table 1. Release of TNF- $\alpha$ and histamine from bone-marrow murine mast cell stimulated with SCF, IgE or a combination of IgE plus SCF.

\begin{tabular}{|c|c|c|c|c|c|c|}
\hline \multirow[t]{2}{*}{ Stimulus } & \multicolumn{3}{|l|}{$\mathrm{TNF}-\alpha(\mathrm{ng} / \mathrm{ml})$} & \multicolumn{3}{|l|}{ Histamine (nM) } \\
\hline & $1 \mathrm{~h}$ & $6 \mathrm{~h}$ & $18 \mathrm{~h}$ & $1 \mathrm{~h}$ & $6 \mathrm{~h}$ & $18 \mathrm{~h}$ \\
\hline Control & $<0.1$ & $<0.1$ & $<0.1$ & $97.20 \pm 0.4$ & $138.9 \pm 8.4$ & $118 \pm 10.3$ \\
\hline SCF & $0.05 \pm 0.001$ & $0.38 \pm 0.08^{*}$ & $0.26 \pm 0.1^{*}$ & $491 \pm 71.5^{*}$ & $626 \pm 26.7 *$ & $262 \pm 24.4^{\#}$ \\
\hline $\operatorname{IgE}$ & $2.65 \pm 0.1$ & $4.11 \pm 2.1^{*}$ & $5.80 \pm 0.1^{*}$ & $\pm 15.5^{*}$ & $355.2 \pm 2.8^{*}$ & $884 \pm 37.1^{*}$ \\
\hline $\mathrm{IgE}+\mathrm{SCF}$ & $3.30 \pm 0.1$ & $14.53 \pm 1.3 * *$ & $10.39 \pm 0.2 * *$ & $1398.9 \pm 173.6 * *$ & $1475.8 \pm 154.3 * *$ & $1589 \pm 156.3^{* *}$ \\
\hline
\end{tabular}

BMMC were stimulated with SCF $(200 \mathrm{ng} / \mathrm{ml})$, IgE $(2 \mu \mathrm{g} / \mathrm{ml})$ plus DNP $(100 \mathrm{ng} / \mathrm{ml})$ or a combination of SCF, IgE plus DNP for $6 \mathrm{~h}$ or $18 \mathrm{~h}$ at $37^{\circ} \mathrm{C}$ in DMEM. After incubation, cells were centrifuged and the cell-free supernatants recovered. TNF- $\alpha$ and histamine levels were measured by ELISA. The results represent the mean SEM of duplicate culture from one typical experiment. Similar data were obtained in two other experiments. ${ }^{*} \mathrm{p}<0.0001$, when compared with control. ${ }^{* *} \mathrm{p}<0.01$, when compared with IgE group. ${ }^{*} \mathrm{p}<0.005$, when compared with control.

\section{Results}

Detection of TNF- $\alpha$ and histamine in the SCF and/or IgE-stimulated BMMC

Mast cells are important cellular sources of different multifunctional cytokines [23] and have been identified as the only resident cell capable of storing TNF- $\alpha$ in cytoplasmic granules. Several studies demonstrate that mast cell-derived TNF$\alpha$ serve as a central component of host defense against bacterial infection and is crucial for establishing cytokine networks that lead to the recruitment of leukocytes [24, 25]. Our initial investigation demonstrated that although SCF (200 $\mathrm{ng} / \mathrm{ml}$ ) was able to induce release of mast cell-derived TNF$\alpha$, a significantly higher release of TNF- $\alpha$ was observed in mast cell culture supernatant after IgE stimulation (Table I). As previously reported, SCF $(200 \mathrm{ng} / \mathrm{ml})$ was able to further up-regulate TNF- $\alpha$ production at both 6 and $18 \mathrm{~h}$ post IgE stimulation (Table I). These results suggest that mast cells have differential TNF- $\alpha$ production dependent on the stimulus and that both IgE and SCF induce de novo production of TNF in addition to that released immediately upon stimulation.

Histamine release by mast cells has an important function during an immediate reaction, as it can induce vascular permeability causing vasodilatation and edema [26]. In mast cell cultures increased histamine levels were present by $1 \mathrm{~h}$ after SCF stimulation and remained elevated for the next $6 \mathrm{~h}$. After $18 \mathrm{~h}$, histamine levels in the cell culture were diminished. During IgE stimulation, histamine levels were also present by $1 \mathrm{~h}$; continued to increase at $6 \mathrm{~h}$ and by $18 \mathrm{~h}$ even higher levels of histamine could be observed. SCF $(200 \mathrm{ng} / \mathrm{ml})$ had a synergistic effect on histamine release when combined with IgE stimulation (Table I). These results indicate that SCF has a similar propensity as IgE to induce release of histamine.

\section{Production of CC chemokines by bone marrow-derived mast cells (BMMC)}

In order to investigate the role of SCF and/or IgE stimulation for chemokine production by murine mast cells (BMMC), $\mathrm{SCF}$, IgE, or a combination of SCF and IgE were used. We observed that SCF (200 ng/ml)-stimulated BMMC release MDC, TARC and MCP-1, (Fig. 1) into the culture superna- tants. Lower doses of SCF $(0.1-100 \mathrm{ng} / \mathrm{ml})$ showed no significant differences when compared to control (data not shown). The levels of MCP-1 were further augmented at $6 \mathrm{~h}$ when IgE and SCF (100 ng/ml) were added concomitantly (Figure 1E). Interestingly, both SCF and IgE induced CCL22 (MDC) production at very high levels, while TARC production was much more modest. However, the level of CCL17 (TARC) was increase $\sim 4$-fold when IgE and SCF $(100 \mathrm{ng} / \mathrm{ml})$ were added concomitantly (Fig. 1D). The levels of MDC subsequently increase $\sim 5$-fold when both SCF and IgE were added together to the cultured BMMC (Fig. 1B). Overall, these data suggest that mast cells stimulated by SCF and/or IgE are an important source of CC chemokine production, CCL22 (MDC), CCL17 (TARC) and CCL2 (MCP-1).

\section{$S C F$ and IgE-induced CC chemokine receptor expression and $B M M C$ chemotaxis}

Previous data indicated that chemokines have a role in mast cell activation and degranulation. To determine whether SCF and/or IgE could induce the up-regulation of CC chemokine receptors in BMMC, RT-PCR analysis was used. As shown in Fig. 2 both SCF and IgE stimulation were able to signifi-

Table 2. Mast cell chemotaxis activity in absence of SCF.

\begin{tabular}{ll}
\hline Stimulus & $\begin{array}{c}\text { Mast cells } / 10 \mathrm{HPF} \\
\text { Absence of SCF }\end{array}$ \\
\hline Control & $7.5 \pm 5.5$ \\
MIP-1 $\alpha$ & $232.5 \pm 12.5^{*}$ \\
MCP-1 & $367 \quad \pm 31^{*}$ \\
Eotaxin & $171 \quad \pm 69^{*}$ \\
MDC & $15 \quad \pm 5$ \\
MIP-1 $\beta$ & $198 \pm 18.5^{*}$
\end{tabular}

BMMC were obtained from primary bone marrow cultured for 3 weeks in DMEM supplemented with $15 \%$ FCS, IL-3 and SCF as described in Materials and Methods. After 3 weeks, cells were washed and suspended in DMEM in absence of SCF. Cells were loaded in the upper chamber and chemotaxis to CC chemokines $(50 \mathrm{ng} / \mathrm{ml})$ were observed after $2 \mathrm{~h}$ at $37^{\circ} \mathrm{C}$. The results represent the mean SEM of duplicate culture from one typical experiment. Similar data were obtained in two other experiments. ${ }^{*} \mathrm{p}<0.001$ when compared with control. 

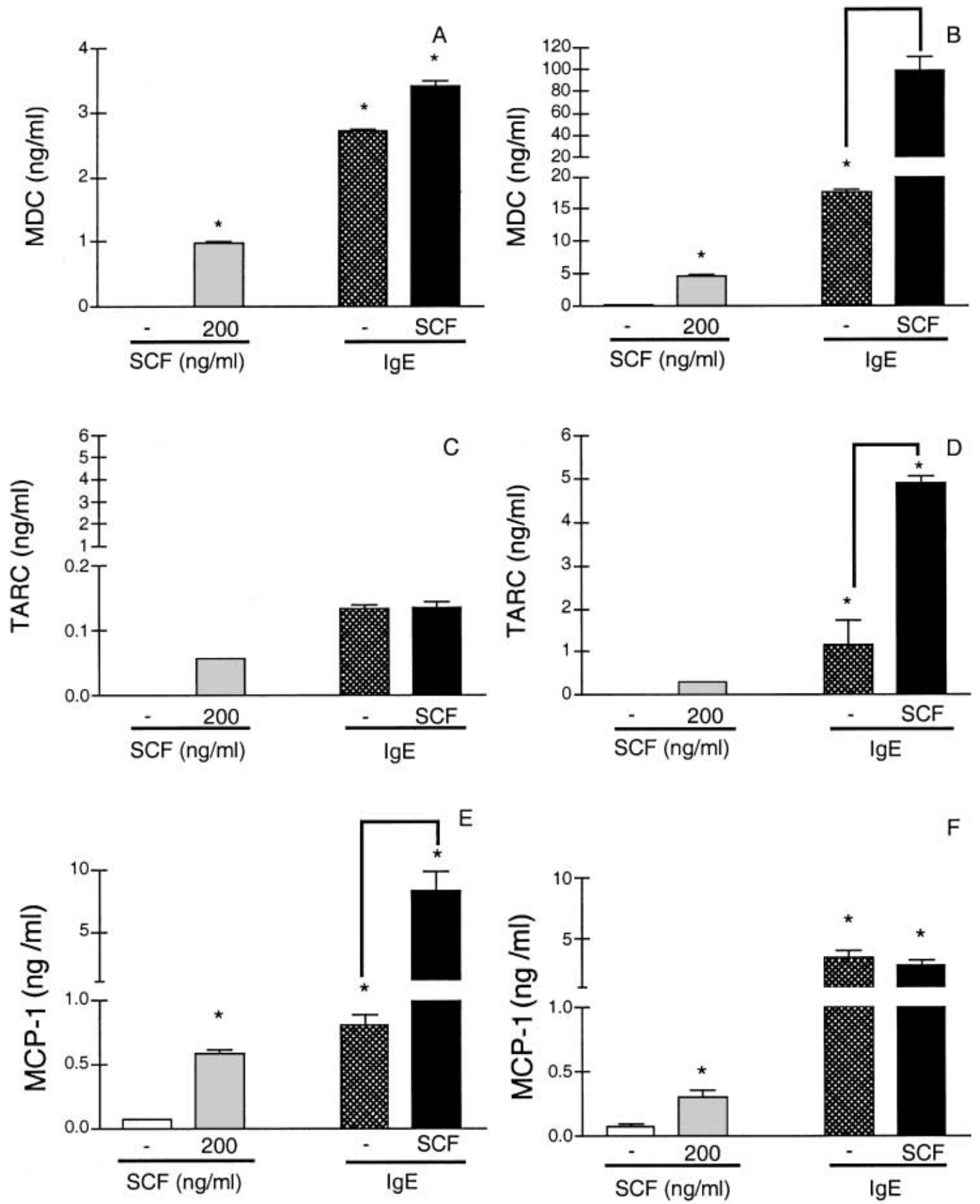

Fig. 1. Incubation of normal mast cells with SCF (200 ng/ml) and/or IgE $(2 \mu \mathrm{g} / \mathrm{ml})+$ DNP induces MDC (A, B), TARC (C, D), MCP-1 (E, F) production by $6 \mathrm{~h}$ and $18 \mathrm{~h}$ respectively. The results represent the means \pm SEM of triplicate cultures from one typical experiment. Similar data were obtained in two other experiments. ${ }^{*} \mathrm{p}<0.001$. No significant increase in the chemokines was observed at $1 \mathrm{~h}$ time points.

cantly up-regulate CCR1, CCR2, CCR3 and CCR5 mRNA expression in BMMC, while co-activation with both stimuli did not further upregulate the receptors.

In order to ascertain whether these receptors were functionally expressed on mast cells we utilized mast cell chemotaxis assays. The data in Table II indicates that mast cells grown in the presence of SCF have the ability to migrate to $\mathrm{CC}$ chemokine ligands that are specific for the various chemokine receptors. The migration patterns match the RTPCR expression patterns described in Fig. 3. That is that ligands for CCR1 (MIP-1 $\alpha$ ), CCR2 (MCP-1), CCR3 (eotaxin), and CCR5 (MIP-1 $\beta$ ), but not MDC and TARC (CCR4), 


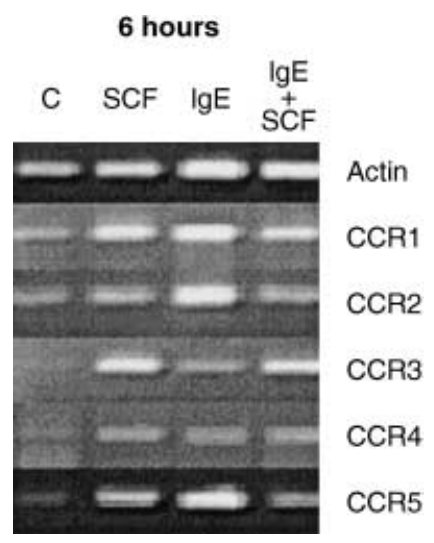

Fig. 2. Incubation of bone marrow-derived mast cells with SCF (200 $\mathrm{ng} / \mathrm{ml}), \operatorname{IgE}(2 \mu \mathrm{g} / \mathrm{ml})+\mathrm{DNP}$, or a combination of SCF $(100 \mathrm{ng} / \mathrm{ml}) \mathrm{plus}$ IgE up-regulate CCR1, CCR2, CCR 3 and CCR 5 expression by $6 \mathrm{~h} .2 \mu \mathrm{g}$ of total mRNA purified from bone marrow-derived mast cell was used in RT-PCR analysis. Similar results were obtained from 2 repeat experiments

induced the migration of BMMCs in chemotactic assays. No further increase in chemotaxis could be detected when the BMMC were stimulated overnight with SCF or IgE (data not shown). In additional studies, we also determined that neither MDC (CCL22) nor TARC (CCL17) had any effect on $B M M C$ degranulation (data not shown).

\section{Discussion}

The participation of SCF in allergic inflammation can induce airway hyperreactivity via direct mast cell activation as well as having a role in eosinophil accumulation [27, 28]. Previous work has demonstrated that SCF and IgE were able to stimulate BMMC to release TNF- $\alpha$, an important pro-inflammatory mediator involved in the allergic inflammatory response [29]. In the present studies, although SCF was able to produce similar levels of histamine to be released from long-term cultures of mast cells, $\operatorname{IgE}$ stimulation induced a ten-fold greater increase in TNF. There is evidence for increased TNF- $\alpha$ expression in asthmatic airway [30] and after IgE-mediated activation in sensitized lungs [29, 31]. TNF- $\alpha$ may have an important amplifying effect in allergic asthmatic inflammation $[22,32]$, with functions that occur in combination with other cytokines as part of cytokine networks [33]. The fact that SCF and IgE stimulation in combination induce 2-3 fold more TNF demonstrates how these activating stimuli synergize during allergic responses. Subsequently, TNF- $\alpha$ would further contribute to the inflammatory response by stimulating airway epithelial cells to produce cytokines and chemokines, including RANTES (CCL5), IL-8 (CXCL8) and GM-CSF [34-36]. This is an issue that may need to be revisited given the described role of SCF for TNF production during bacterial septic response [37]. Interestingly, histamine release was similar between SCF and IgE stimulation.

IgE mediated chemokine release was potentiated by SCF in the same manner as histamine and TNF. Other authors [38, 39] have observed a relationship between histamine and CC chemokines. Treatment of mice with eotaxin (CCL11) [40] produced a time-dependent accumulation of eosinophils that was significantly reduced if the animals were pre-treated with histamine $\mathrm{H} 1$ antagonist. Thus, the effect of mediators from mast cells on other cell populations has not been fully appreciated. The fact that SCF also appears to be an important mast cell activator to induce $\mathrm{CC}$ chemokine production along with histamine and TNF suggests a generalized upregulation of inflammatory recruitment responses by activated mast cells. The coordination and intensity of the inflammatory response may, in part, be induced by the mast cells during allergic responses. This latter hypothesis is supported by recent investigations of SCF-deficient allergic mice that demonstrated significantly less inflammation and airway hyperreactivity upon allergen challenge [27]. The data in the present studies are consistent with previous investigations demonstrating the ability of SCF to augment MCP-1 production as well as studies demonstrating chemokine production from mast cells during allergic responses [42-48]. SCF up regulating IgE-induced MCP-1 (CCL2) production by stimulated mast cells may be an important mechanism mediating MCP-1 production in allergic inflammatory response. However, the most highly activated chemokine during the mast cell treatment was monocyte-derived chemokine (MDC) (CCL22). MDC was significantly upregulated by both SCF and IgE and was further enhanced five fold higher when mast cells were activated with both SCF and IgE. MDC (CCL22) may have an important role during allergic responses via its ability to induce dendritic cell movement and preferentially recruit $\mathrm{Th} 2$ type cells via CCR 4 [49]. A recent study has indicated that MDC plays an important role in inflammation and airway hyperreactivity in mouse models of allergic asthma [50]. Thus, this chemokine may be a key mediator produced by stimulated mast cells during allergic responses and contribute to the maintenance of the late phase via the perpetuation of the Th2 type responses. TARC (CCL17) was significantly produced by IgE but not SCF alone; however; it was further upregulated when mast cells are activated with both SCF and IgE. Previous studies have shown TARC (CCL17) production by murine keratinocytic cell line and during the atopic dermatitis-like lesions, a characteristic mast cell degranulated lesions that have high level of IgE [51]. Thus, TARC may contribute to maintenance of the inflammatory process mediated by mast cells and $\operatorname{IgE}$ in presence of SCF.

The up regulation of chemokine receptors by SCF and IgE on the BMMCs indicate that during allergic responses the mast cells become more susceptible to chemokines stimulation. This is a significant issue. One aspect of chemokine biology is the ability of several chemokines to cause mast cell activation [52, 53]. In fact, recent studies indicate that activation of mast cells with MCP-1 (via CCR2) can induce mediator release, including histamine and leukotriene release, further exacerbating airway hyperreactivity [54]. Although the functional assay that was performed in the present studies was mast cell chemotaxis, it may be the case that a primary role for chemokines in mast cell biology is activation not migration. This may especially be the issue in fixed tissue mast cells in the upper airways where movement is not necessary. The overall impact of multiple chemokine receptors on cells is presently unclear [55], but future investiga- 
tions will likely demonstrate a diverse array of chemokinemediated functions.

Overall, these studies indicate that SCF can upregulate the expression of chemokines and chemokine receptors on mast cells and along with IgE, SCF may play a significant role in the activation and inflammation during allergic responses. Future studies will examine the significance of expressing multiple chemokine receptors on the mast cells and whether there are differences in function when the different receptors are ligated.

Acknowledgements. We thank Pam Lincoln and Holly Evanoff for technical assistance. This study was supported by NIH Grants, HL59178, AI36302 and HL31963. S.H.P.O. is a postdoctoral fellow of the Fundacao de Amparo a Pesquisa do Estado de Sao Paulo (FAPESP), Brazil.

\section{References}

[1] Kubes P, Granger DN. Leukocyte-endothelial cell interactions evoked by mast cells. Cardiovasc Res 1996; 32(4): 699-708.

[2] Holgate ST. Mast cells, mediators and disease. London: Klurg Academic Publishers, 1988.

[3] Burd PR, Rogers HW, Gordon JR, Martin CA, Jayaraman S, Wilson SD et al. Interleukin 3-dependent and -independent mast cells stimulated with IgE and antigen express multiple cytokines. J Exp Med 1989; 170: 245-57.

[4] Taub DD. Chemokine-leukocyte interactions. The voodoo that they do so well. Cytokine Growth Factor Rev 1997; (4): 355-76.

[5] Baggiolini M. Chemokines and leukocyte traffic. Nature 1998; 392: $565-8$

[6] Adams DH, Lloyd AR. Chemokines. leukocyte recruitment and activation cytokines. Lancet 1997; 349: 490-5.

[7] Bossink AWJ, Paemen L, Jansen PM, Hack CE, Thijs LG, Van Damme J. Plasma levels of the chemokines monocyte chemotactic proteins-1 and 2- are elevated in human sepsis. Blood 1995; 86: 3841-7.

[8] Noris M, Bernasconi S, Casiraghi F, Sozzani S, Gotti E, Remuzzi $\mathrm{G}$ et al. Monocyte chemoattractant protein-1 is excreted in excessive amounts in the urine of patients with lupus nephritis. Lab Invest 1995; 73: 804-9.

[9] Lukacs NW, Strieter RM, Kunkel SL. Leukocyte infiltration in allergic airway inflammation. Am J Respir Cell Mol Biol 1995; 13: $1-6$.

[10] Kurashima K, Mukaida N, Fujimura M, Schroder JM, Matsuda T, Matsushima K. Increase of chemokine levels in sputum precedes exacerbation of acute asthma attacks. J Leukoc Biol 1996; 59: 313-6.

[11] Kaplan AP, Kuna P, Reddigari SR. Chemokines and the allergic response. Exp Dermatol 1995; 4: 260-5.

[12] Wershil BK, Tsai M, Geissler EN, Zsebo KM, Galli SJ. The rat c-kit ligand, stem cell factor, induces c-kit receptor-dependent mouse mast cell activation in vivo. Evidence that signaling through the c-kit receptor can induce expression of cellular function. J Exp Med 1992, 175: 245-55.

[13] Valent P, Spanblochl E, Sperr WR, Sillaber C, Zsebo KM, Agis H et al. Induction of differentiation of human mast cells from bone marrow and peripheral blood mononuclear cells by recombinant human stem cell factor/kit-ligand in long-term culture. Blood 1992; 80: 2237-45.

[14] Galli SJ, Iemura A, Garlick DS, Gamba-Vitalo C, Zsebo KM, Andrews RG. Reversible expansion of primate mast cell populations in vivo by stem cell factor. J Clin Invest 1993, 91: $148-52$.

[15] Coleman JW, Holiday MR, Kimber I, Zsebo KM, Galli SJ. Regulation of mouse peritoneal mast cell secretory function by stem cell factor, IL-3, IL-4. J Immunol 1993; 150: 556-62.
[16] Iemura A, Tsai M, Ando A, Wershil BK, Galli SJ. The c-kit ligand, stem cell factor, promotes mast cell survival by suppressing apoptosis. Am J Pathol 1994; 144: 321-8.

[17] Columbo M, Horowitz EM, Botana LM, MacGlashan DW, Bochner BS, Gillis $\mathrm{S}$ et al. The human recombinant c-kit receptor ligand, rhSCF, induces mediators release from human cutaneous mast cells and enhances IgE-dependent mediator release from both skin mast cells and peripheral blood basophils. J Immunol 1992; 149: 599-608.

[18] Gibbs BF, Arm JP, Gibson K, Lee TH, Pearce FL. Human lung mast cells release small amounts of interleukin- 4 and tumor necrosis factor- in response to stimulation by anti-IgE and stem cell factor. Eur J Pharmacol 1997; 327: 73-8.

[19] Okayama Y, Kobayashi H, Ashman LK, Dobashi K, Nakazawa T, Holgate ST et al. Human lung mast cells are enriched in the capacity to produce granulocyte-macrophage colony-stimulating factor in response to IgE-dependent stimulation. Eur J Immunol 1998; 28: 708-15.

[20] Lukacs NW, Kunkel SL, Strieter RM, Evanoff HL, Kunkel RG, Key ML et al. The role of stem cell factor (c-kit ligand) and inflammatory cytokines in pulmonary mast cell activation. Blood 1996; 87: 2262-8.

[21] Evanoff H, Burdick MD, Moore SA, Kunkel SL, Strieter RM. A sensitive ELISA for the detection of human monocyte chemoattractant protein-1 (MCP-1). Immunol Invest 1992; 21: 39-45.

[22] Falk WR, Goodwin RH, Leonard EJ. A 48-well microchemotaxis assembly for rapid and accurate measurement of leukocyte migration. J Immunol Methods 1980; 33: 239-42.

[23] Gordon JR, Burd PR, Galli SJ. Mast cells as a source of multifunctional cytokines. Immunol Today 1990; 12: 458-64.

[24] Gordon JR, Galli SJ. Mast cells as a source of both preformed and immunologically inducible TNF-alpha/cachectin. Nature 1990; 346: 274-6.

[25] Malaviya R, Ikeda T, Ross E, Abraham SN. Mast cell modulation of neutrophil influx and bacterial clearance at sites of infection through TNF-alpha. Nature 1996; 381: 77-80.

[26] Taub D, Dastych J, Inamura N, Upton J, Kelvin D, Metcalfe D et al. Bone Marrow-derived murine mast cells migrate, but do not degranulate, in response to chemokines. J Immunol 1995; 154: 2393-402.

[27] Campbell E, Hogaboam C, Lincoln P, Lukacs NW. Stem cell factor-induced airway hyperreactivity in allergic and normal mice. Am J Pathol 1999; 154: 1259-65.

[28] Lukacs NW, Strieter RM, Lincoln PM, Browell E, Pullen DM, Schock HJ et al. Stem cell factor (c-kit ligand) influences eosinophil recruitment and histamine levels in allergic airways inflammation. J Immunol 1996; 156: 3945-51.

[29] Ohno I, Ohkawara Y, Yamauchi K, Tanno Y, Takishima T. Production of tumor necrosis factor with $\mathrm{IgE}$ receptor triggering from sensitized lung tissue. Am J Respir Cell Mol Biol 1990; 4: 285-9.

[30] Bradding P, Roberts JA, Britten KM, Montefort S, Djukanovic R, Mueller R et al. interleukin- $4,-5$ and -6 and tumor necrosis factor$\alpha$ in normal and asthmatic airways. Evidence for the human mast cell as a source of these cytokines. Am J Respir Cell Mol Biol 1994; 10: 471-80.

[31] Ohkawara Y, Yamauchi K, Tanno Y, Tamura H, Outani H, Nagura $\mathrm{H}$ et al. Human lung mast cells and pulmonary macrophages produce tumor necrosis factor- in sensitized lung tissue after IgE receptor triggering. Am J Respir Cell Mol Biol 1992; 7: 385-92.

[32] Shah A, Church MK, Holgate ST. Tumor necrosis factor $\alpha$. A potential mediators of asthma. Clin Exp Allergy 1995; 25: $1038-44$.

[33] Eder J. Tumor necrosis factor $\alpha$ and interleukin 1 signaling: Do MAPKK kinases connect it all? Trends Pharmacol Sci 1997; 18: 319-22.

[34] Berkman N, Robichaud A, Krishnan VL, Roesems G, Robbins RA, Jose PJ et al. Expression of RANTES in human airways epithelial cells: Effect of corticosteroids and interleukin-4, 10 and 13. Immunology 1995; 87: 599-603.

[35] Kwon O, Au BT, Collins PD, Mak JC, Robbins RR, Chung KF et al. Tumor necrosis factor-induced interleukin- 8 expression in pul- 
monary cultures human airway epithelial cells. Am J Physiol 1994; 267: L398-405.

[36] Cromwell O, Hamid Q, Corrigan CJ, Barkans J, Meng Q, Collins PD et al. Expression and generation of interleukin-8, IL- 6 and granulocyte colony-stimulating factor by bronchial epithelial cells and enhancement by IL- $1 \beta$ and tumor necrosis factor- $\alpha$. Immunology 1992; 77: 330-7.

[37] Maurer M, Echtenacher B, Hultner L, Kollias G, Mannel DN, Langley KE et al. The c-kit ligand, stem cell factor, can enhance innate immunity through effects on mast cells. J Exp Med 1998; 188: 2343-8.

[38] Perretti M, Harris JG, Flower RJ. A role for endogenous histamine in interleukin-8-induced neutrophil infiltration into mouse air pouch: investigation of the modulatory action of systemic and local dexamethasone. Br J Pharmacol 1994; 12: 801-8.

[39] Rot A. Binding of neutrophil attractant/activating protein-1 (interleukin-8) to resident dermal cells. Cytokine 1992; 4: 347-52.

[40] Jose PJ, Adcock IM, Griffiths-Johnson DA, Berkman N, Wells TNC, Williams TJ et al. Eotaxin: cloning of an eosinophil chemoattractant cytokine and increased mRNA expression in allergenchallenged guinea-pig lungs. Biochem Biophys Res Commun 1994; 205: 788-94.

[41] Conti P, Pang X, Boucher W, Letourneau R, Reale M, Barbacane $\mathrm{RC}$ et al. Monocyte chemotactic protein- 1 is a proinflammatory chemokine in rat skin injection sites and chemoattractants basophilic granular cells. Int Immunol 1997; 10: 1563-70.

[42] Baghestanian M, Hofbauer R, Kiener HP, Bankl HC, Wimazal F, Willeim $\mathrm{M}$ et al. The c-kit ligand stem cell factor and anti-IgE promote expression of monocyte chemoattractant protein-1 in human lung mast cells. Blood 1997; 90: 4438-49.

[43] Alam R, Kumar AR, Anderson-Walters D, Forsythe PA. Macrophage inflammatory protein- 1 alfa and monocyte chemoattractant peptide-1 elicit immediate and late cutaneous reactions and activate murine mast cells in vivo. J Immunol 1994; 152: 1298-303.

[44] Conti P, Reale M, Barbacane RC, Letourneau R, Theoharides TC. Intramuscular injection of hrRANTES causes mast cell recruitment and increased transcription of histidine descarboxylase in mice: lack of effects in genetically mast cell-deficient $\mathrm{W} / \mathrm{Wv}$ mice. FASEB J 1998; 12: 1693-700.

[45] Conti P, Reale M, Barbacane RC, Felano M, Grilli A, Theoharides TC. Mast cell recruitment after subcutaneous injection of
RANTES in the sole of the rat paw. Br J Haematol 1998; 103 : 798-803.

[46] Tedla N, Wang HW, McNeil HP, Di Girolamo N, Hampartzoumian $\mathrm{T}$, Wakefield $\mathrm{D}$ et al. Regulation of T lymphocyte trafficking into lymph nodes during an immune response by the chemokines macrophage inflammatory protein (MIP)-1 alfa and MIP-1 beta. J Immunol 1998; 161: 5663-72.

[47] Wang HW, Tedla N, Lloyd AR, Wakefield D, McNeil PH. Mast cell activation and migration to lymph nodes during induction of an immune response in mice. J Clin Invest 1998; 102: $1617-26$.

[48] Lukacs NW, Hogaboam CM, Kunkel SL, Chensue SW, Burdick MD, Evanoff HL et al. Mast cell produce ENA-78, which can function as a potent neutrophil chemoattractant during allergic airway inflammation. J Leukoc Biol 1998; 63: 746-51.

[49] Imai T, Chantry D, Raport C J, Wood C L, Nishimura M, Godiska $\mathrm{R}$ et al. Macrophage-derived chemokine is a functional ligand for the CC chemokine receptor 4. J Biol Chem 1998; 273; 1764-8.

[50] Gonzalo J A, Pan Y, Lloyd CM, Jia GQ, Yu G, Dussault B et al. Mouse monocyte-derived chemokine is involved in airway hyperreactivity and lung inflammation. J Immunol 1999; 163: 403-11.

[51] Vestergaard C, Yoneyama H, Murai M, Nakamura K, Tamaki K, Terashima $\mathrm{Y}$ et al. Overproduction of Th2-specific chemokine in $\mathrm{NC}$ /Nga mice exhibiting atopic dermatitis-like lesions. J Clin Invest 1999; 104: 1097-105.

[52] Conti P, Boucher W, Letourneau R, Feliciani C, Reale M, Barbacane RC et al. Monocyte chemotactic protein-1 provokes mast cell aggregation and $\left[{ }^{3} \mathrm{H}\right] 5-\mathrm{HT}$ release. Immunology 1995; 86 : 434-40.

[53] Conti P, Pang X, Boucher W, Letourneau R, Reale M, Barbacane $\mathrm{RC}$ et al. Impact of Rantes and MCP-1 chemokines on in vivo basophilic cell recruitment in rat skin injection model and their role in modifying the protein and mRNA levels for histidine decarboxylase. Blood 1997; 89: 4120-7.

[54] Campbell EM, Charo IF, Kunkel SL,. Strieter RM, Boring L, Gosling $\mathrm{J}$ et al. Monocyte chemoattractant protein-1 mediates cockroach allergen-induced bronchial hyperreactivity in normal but not CCR2-/- mice. the role of mast cells. J Immunol 1999; 163: 2160-7.

[55] Murphy PM. Chemokine receptors: structure, function and role in microbial pathogenesis. Cytokine Growth Factor Rev 19961: $47-64$. 